\title{
Place Name Types and Derivations for Sinai
}

\section{Generic Place Names}

Ain natural spring of water, Ain Akhdar $=$ Green Spring.

Arish shelter made from palm fronds, Wadi el Arish.

Bilad at Tor Land of Mountains, original name for south Sinai.

Bir well.

Bueb door, like a narrow place in a wadi.

Dhayga narrows, as where a wadi is constricted by mountains.

Galt cistern.

Gebel mountain, also commonly shown as jebel, Gebel

Hadid=Iron Mountain.

Jawra flat plain surrounded by sand dunes.

Maghara cave, Gebel Maghara=Cave Mountain.

Minit at Tor Port of the Mountains, now simply rendered "Tor."

Moyat water, as in a pond.

$N a q b$ pass between mountains, Naqb el Mirad=Pass of the Wa-

tering Place, Naqb Buderah=Pass of the Sword, Naqb

Hawy $=$ Pass of the Wind.

Qa plain.

Ras peak or headland, Ras Ahmar=Red Peak, Ras Mohammed= Headland of Mohammed, the tip of the Peninsula extending into the Red Sea.

Sabkha salt flat.

Seil the lower reaches of a wadi or dry torrent bed, often where several wadis come together.

Sharm break in the coastline, a bay, Sharm el Sheikh=Bay of the Sheikh.

Shust summit.

Sidd dry waterfall.

Tawil tall, pointed peak.

Tell hill, often a ruin.

Themila area of shallow groundwater. 
Wadi stream course, usually dry, Wadi Mukateb=Written Valley, inscriptions.

Yirga twisting wadi, Ain Yirga=Spring of the Twisting Wadi.

\section{Zoomorphic Place Names}

Ghazala gazelle, Wadi Ghazala=Gazelle Valley.

Halal goat, Gebel Halal=Mountain of the Goats.

Humr fruit of the Nitraria retusa, a nitrogen-fixing plant with thorns and fleshy leaves.

Ifai viper, Wadi Um Ifai = Valley of the Mother of Vipers.

Kuntilla a grass, Bromus sinaicus, Sinai brome.

Sa'al acacia tree, Wadi Sa'al.

Sidri thorny shrub, Zizyphus spina-christi.

Sulaf herb, Capparis cartilaginea.

\section{Historic and Legendary Place Names}

Badiet at Tih Desert of the Wandering (Children of Israel), most of central Sinai.

Dahab gold. Thought to be the port for Solomon's gold coming from Ophir, Dahab is an unlikely spot for a port serving Jerusalem.

Deir el Arbain Convent of the Forty (forty martyrs killed by Bedouin raiders).

Magad Sayidna Musa Sitting Place of the Lord Moses /a red granite rock near Watia Pass).

Sabkhet el Bardawil Lake Baldwin (named for Baldwin I, King of Jerusalem, who died here in A.D. I I 18 ).

Serbal Baal's Vineyard, as in Gebel Serbal.

Sikket Shoeib Path of Jethro, near Gebel Musa and St. Catherine.

\section{Miscellaneous Place Names}

Abu Tarfa Father of Tamarisks (a large grove of manna-bearing trees).

Um Shomer Mother of Darkness (a peak in the Sinai Massif composed of dark igneous rock).

Um Dud Mother of Worms. 